\title{
The Gutenberg Fallacy and the History of Printing among the Mongols
}

\author{
Johan Elverskog
}

In a 1969 Playboy interview Marshall McLuhan proclaimed that the printing press was "directly responsible for the rise of such disparate phenomena as nationalism, the Reformation, the assembly line and its offspring, the Industrial Revolution, the whole concept of causality, Cartesian and Newtonian concepts of the universe, perspective in art, narrative chronology in literature, and a psychological mode of introspection or inner direction that greatly intensified the tendencies toward individualism and specialization" (Kingwell 2013). Or in short, the man behind "the medium is the message" was an avid promoter of the notion that basically the entire modern world - from neo-liberal democracy to monster truck rallies - grew out of Gutenberg's invention of movable type.

By any stretch of the imagination this is an unbelievably bold - if not completely ludicrous - claim; however, as we all know, it is one that drives much of the thinking and writing about the history of printing. Indeed, it is this very same conceptual framework that undergirds not only the current flurry of conferences and scholarship on the global history of printing, ${ }^{1}$ but also this very project and volume as well. Moreover, it is this same master narrative - and admittedly its re-orientation - that also drives the current nationalist-fueled scholarship that aims to find the origin of printing in China, Korea, or Japan (Kornicki 2012). Yet, regardless of where printing actually originated the main thrust of all this "work" - as most famously manifested in the opening ceremony of the 2008 Beijing Olympic Games (Bachner 2014, 1-6) - is simply to confirm that printing was not solely a European invention. Thus by extension as with the discourse about the "four great inventions" (Amelung 2003) - the argument is that the roots of modernity actually stretch back to Asia. And,

1 The list of such work and projects is obviously long, thus here let me just cite one of the latest: "International Conference on the Technology and Development of Metal Movable-Type Printing and Print Culture in East Asia" (University of California, Berkeley, September 28, 2013). In regards to Inner Asian book and printing culture see the review of all such recent and on-going projects in Almogi 2014.

(C) JOHAN ELVERSKOG, 2016 | DOI 10.1163/9789004316256_004

This is an open access chapter distributed under the terms of the Creative Commons Attribution-

Noncommercial 3.0. Unported (CC BY-NC 3.0) License. 
of course, within this larger intellectual project the one invention most freighted with tension - on account of McLuhan and Eisenstein - is the history of printing, since it has indisputably been held up as the key innovation that ushered in the modern world.

Yet, as Marks has so eloquently put it, such winner-and-loser narratives largely miss the point of world history, and thus they need not detain us here (2002, 1-16). Nevertheless, even if one does so there still remains the related issue about the supposedly fundamentally transformative nature of printing. Indeed, we may want to stop for a moment and ponder - as many other scholars have done ${ }^{2}$ - about the very notion that printing is in fact a transformative invention. Or, at the very least, we may want to explore whether the speculations of McLuhan and Eisenstein about printing are applicable in all times and places. In fact, what I want to argue herein is precisely that printing actually had very little impact among the Mongols.

\section{Thinking Printing}

In making the argument that printing may not have been as radically transformative in all times and places I am not arguing that the scholarship on the global history of printing should be dismissed out of hand. Quite the opposite in fact, since it is precisely such work that is challenging one of the last rickety planks upholding the edifice of Eurocentrism and thereby providing us with a better understanding the global interconnections that went into shaping the world of today. And, as such, it is vital to recognize that modernity did not simply flow out of a fifteenth century German workshop. Indeed, the scholarship on global printing therefore plays a vital role in problematizing the conventional Eurocentric narrative of modernity. Yet, at the same time as doing so, we also need to be cognizant of the potential inadvertent reification of this model simply by studying the history of printing; since by itself it virtually encapsulates modernity as seen in McLuhan's argument cited above. Indeed, consciously or not, simply by making printing the topic of our research we are all by default operating in the shadow of Gutenberg and the larger narrative of European modernity.

Yet, in saying that, it also needs to be noted that this has not always been the case. Or as Joseph Dane has boldly put it: "the entire notion of Print Culture is constructed in bad faith" (2009). Indeed, the elevation of printing in the

2 On the re-evaluation of printing's impact see Febvre and Martin 1990, Chartier 1994, Johns 1998, McKitterick 2003, and Baron et al. 2007. 
teleological narrative of the modern West is premised on its very own logic that values the socially transformative potentials of technology, which is something that is largely unique to the Western world. Moreover, even in the West it is actually a rather new development as well. Thus as scholars who specialize in the Gutenberg Bible have recently pointed out: based on the different font structures and a whole range of other issues, the fact of the matter is that today we do not really know how the Gutenberg Bible was actually printed. In fact, the conventional image of the uniform dies in little boxes, assembled into pages, and then printed on a press, seems to be wholly inaccurate in relation to how Gutenberg actually did his work. Rather, as Dane and others have pointed out, all of the iconic images of "early printing presses" that are found in books and now all over the web, are actually from the sixteenth century. Or in other words, these images reflect how printing was done then, not how Gutenberg did it. Moreover, it was only then, in the sixteenth century, that the value of printing was beginning to be recognized, whereby it then became a foundational part of the teleological narrative of modernity. Before that, however, it is important to recognize that no one in Europe apparently thought that printing was anything as monumentally important as people like McLuhan have claimed it to be. Rather, it was just a technique. One, moreover, that no one bothered to even document since it was of such little relevance (Dane 2003, 10-21). Indeed, it is precisely for this reason that today we do not know how the Gutenberg Bible was printed.

To my mind this is an important point since it problematizes the whole narrative arc of not only printing, but also modernity, which is very often built on the notion whereby technology has the potential to be a positive force for social transformation. And since this idea is so deeply engrained in our own narratives of modernity - and, of course, they have now been taken to even newer heights by the utopian fantasies of the technologists in Silicon Valley (Morozov 2013) - it is important to recall that such a narrative is not a universal reality. Rather, as Furth has pointed out, the classic "Needham question" of who came first, and why, is fundamentally misguided since it is based upon the teleological narrative of the modern West. Thus as she has pointed out, this narrative elevation of printing and technology writ large is a purely European phenomenon. In East Asia, on the other hand, and indeed everywhere else that printing arose before it did in the West - including Inner Asia and the Middle East - where there was no conception of the "socially transformative potentials of technology," there simply is no history of printing. No one cared about it.

In China, for example, where one would assume that much would be made of printing there is virtually nothing on it in the historical record (Barrett 
2014). Most notably, the most comprehensive work on technologies of the late imperial period, Song Yingxing's 宋應星 seventeenth-century Tiangong kaiwu (“Works of Heaven” 天工開物), has a section on paper-making but nothing on printing. An omission that Schäfer in her work on Song's thought and work has argued is because he did not think printing involved transformation, which was the key element of his whole intellectual process (Schäfer 2011, 243). ${ }^{3}$ Yet even if that was indeed the case the fact that printing is so wholly absent in the Chinese historical record still needs to be explained. Joseph McDermott, for example, while researching his book A Social History of the Chinese Book, could not find any descriptions of "woodblock printing technology in premodern sources, and found them only in nineteenth century writings by Western missionaries who were looking into ways to propagate translations of the Christian Bible. So through most of Chinese history, it would seem that Chinese didn't celebrate printing as a major technical achievement of their civilization" (Furth 2009, 2).

It is this fact that therefore goes a long way in explaining why the origin of printing is so bitterly debated. Was it in China under the Buddhist empress Wu Zetian 武則天 (Barrett 2008), or was it in Korea as archaeological records would seem to confirm? Whatever the case may be, the point I want to make here is that the reason that we do not have a definitive answer to this question is that at the time no one in China, Korea, or Japan actually cared enough about printing to make anything of its "discovery." Much less did they see they see the socially transformative potentials of this particular technology. And, as noted above, it was actually the same in Europe until the sixteenth century when printing became part of the technological narrative of modernity that Europeans had come to tell about themselves.

3 At the same time Schäfer does believe that printing had a "Montaigne effect;" namely, on account of the explosion of printing in Ming-Qing China Song Yingxing was actually able to investigate all kinds of sources and thereby compare things, which led him to vocally call for an examination of all statements. It also led him to critique people, like the new philologists (Elman 1984), who just repeated the classics when evidence clearly showed that it was false. Such as when Zhu Xi 朱喜 in his Comprehensive Mirror for the Aid in Government (Zizhi Tongjian Gangmu 資治通鑑綱目) talked about there appearing two suns and two moons, which led Song to critique uncritical bookish learning: "His notion of knowledge was based on universal principles and orderly proceedings, an approach that allowed no obscurities such as two sons or two moons. He called for a critical assessment of the multitude of books and materials made available to the scholar by commercial printing. Instead of blindly following the assumptions of written accounts, Song demanded reliable verification by observation of all facts at hand" (Schäfer 2011, 237). 
Thus, even though the aim of this entire project is to look precisely at how printing changed and transformed the Inner Asian world, I think it is important to be cautious about so readily buying into this particular master narrative. Most notably, I think it is vital to recognize that for most peoples around the world printing was not anything of importance, much less a revolutionary technology. Rather, more often than not, printing was recognized simply as a rather a low level craft that was considered of very little cultural, social, or technological importance. Printing was therefore not considered to be a harbinger of radical change; moreover, quite simply, it did not in fact usher in a new age as so often imagined in the West. It is thus within such a framework that I believe that we need to think about the history of printing among the Mongols.

\section{$2 \quad$ Printing among the Mongols}

As with most things that the Mongols did their involvement with printing was precociously early and on a massive scale. Indeed, only a few short decades after developing a written script we already have an outpouring of printed works ranging from Buddhist ones such as the Mañjuśrināmasamgiti (Weiers 1967) and Sa skya Panḍita's Treasury of Aphoristic Jewels (Sa skya legs bshad, Subhāsitaratnanidhi; Ligeti 1964) and to Chinese works like the Classic of Filial Piety (Xiaojing 孝經; Cleaves 1982, 70), as well as imperially-sanctioned printed calendars (Franke 1962; Kara 1979). Yet these works from the early fourteenth century were only the beginning. Thus in the post-Yuan period (1368-1644) we have evidence of both multi-volume and multi-lingual printed works from the Ming period (Cleaves 2001), and then, beginning with the second conversion and then reaching its crescendo during the Qing period (1644-1911) there was a veritable tsunami of printed works. Of course, by now most of this printed material has been amply documented, catalogued, and commented upon by a range of scholars, but especially by the monumental labors of Walther Heissig. ${ }^{4}$ And no doubt one reason for this sustained scholarly attention on Mongolian printing is precisely the importance placed upon printing in the West. Thus, on account of the Gutenberg shadow, the fact that the Mongols also had a long and illustrious history of printing was clearly important. Indeed, it is precisely because of this discourse that we now know a great deal about Mongolian

4 Some of Heissig's most important works on Mongol print and manuscript culture include 1954, 1962, 1976. 
print culture, such as which elites paid for these works, where and how they were prepared, as well as who used them. ${ }^{5}$

Thus, in thinking about this history, as well as all the scholarship on the history of Mongolian printing, one thing that is important to note is that nowhere in any of this material - or the broader historical corpus - is there ever any claim by the Mongols that printing by itself is either a revolutionary innovation, or in anyway socially transformative, or even anything to be noted. Printing is simply a method of mass production. Moreover, nowhere in any of the Mongol printed material - be it from the Yuan, Ming, or Qing period - is printing, by itself, held up - or categorized - as something of note. Rather, printing was something that was simply done more often than not for Buddhist merit, or to project state power, or much later, to make money by printing what sold to the small community of literate Mongols.

Indeed, in this regard, it may be valuable to cite one of our earliest extant colophons to get a better sense of how the Mongols actually spoke about printing:

Knowing well of the benefits for whoever worships mindfully with an intent to rely on the fully enlightened Buddha Teacher's preaching of the Big Dipper Sūtra, Urug Böke, a Great Parasol Holder, continually recited [this text] with humility and a reverent and pure mind. [He prepared this text] because he prays for the intercession of his blessing, hoping for the long life of the Meritorious Lord, an incarnation of the Buddha who performs Liberation, Tug Temür, and wishes that he will be the greatest Emperor of all, he being a pure minded Bodhisattva Lord. Having learnt Wisdom and Skill and Means he will take the throne of Sechen [Khubilai] Khan.

[Previously], whoever wished one's own mind to be free of attachments and doubts, had to produce faith in this Dharma in Uygur, since this Dharma Sūtra was not translated. Saying, "In order to have many Mongol subjects worship it with faith," I [Urug Böke], had it translated into pure Mongolian. In order to accomplish my idea, "To satisfy the wishes of a thousand people, and thus satisfy their desires," one thousand complete copies were printed and all were disseminated.

By the power of the fruit of this good merit may the Lord Emperor, the Queen, the Imperial lineage, all eternally rejoice, spread merit, and finally obtain the sanctity of the Buddha. May the agitating enemies of the Empire be pacified, and there be no evil spirits and obstacles. May all of

5 The best overview of Mongolian book culture - both manuscript and printed - is Kara 2005 . 
the various weathers and rains come at the proper time, may there be no destruction or insufficiency of the livestock, and may whatever I think and speak be accomplished. By means of this scripture may my wishes in this world, and the wishes of this world of my parents, relatives and children, living and deceased older and younger brothers and all living beings be satisfied in this world, and may they all reach the peaceful world of Sukhāvatī.

In the first year of [Toghon Temür] Tianli's reign, a Dragon year [1328], on the first day of the tenth month, wooden blocks [of this sūtra] were carved. This book was brought from India by an Indian pandița and the wise Xuan Zang, and it was translated in China. When it completely spread in the Land of Supreme Customs [i.e. the Yuan dynasty], the nobles and officials of the Great Emperor gave rise to Bodhicitta and became complete in their faith, wisdom and samādhi-dhyāna.

When he brought these things to mind, Parasol Keeper and Chief Censor Urug Böke had the Lord of the Religion of the Uygurs, Prajñāsin translate it into Mongolian, and had two thousand copies printed. Alin Tämür translated it into Uygur, and a thousand woodblock prints were collected and distributed as Dharma alms among the Mongols and Uygurs. The Grand Empress Dowager, who had previously held the principles of the Mongolian religion, truly entered the Buddha's Dharma and experienced the tranquility of the gunas of meditation by the blessing of this scripture. Afterwards in the Ding Ox year [1337], the translator Matiphala and Śrī Ānandavajra, at Gung Thang monastery, corrected and translated it into Tibetan language and script (Elverskog 2008, 114-118)

Thus as is evident from this passage, the art of printing by itself was not something to cherish, much less a technology that could change Mongolian society. Rather, for the Mongols - or at least Urug Böke - printing was instead a technique that could be harnessed to promote religious doctrines and practices.

Yet, above and beyond this apparent lack of critical reflection upon the potential impact of printing among the Mongols themselves - which is a phenomenon clearly not unique to the Mongols - what is even more interesting to note about the history of printing among the Mongols is that even though the printing of Mongolian material came to be on a monumental scale, it apparently had very little impact in Mongolian culture more broadly. Indeed, in complete contradiction to the whole narrative of printing as ushering in modernity - or printing as fundamentally changing human consciousness and society - there is seemingly no evidence for this in the case of Mongolian printing. As a result, what needs to be recognized is that even though there was all 
this printing going on in the Mongolian world, the Mongols - and Mongolian culture - remained not only largely the same as in its pre-printing age, but also that the Mongols continued to be by and large a manuscript culture.

These two facts clearly need to be explained. Not not only since we have been charged with reflecting on the potential impact of printing in the Inner Asian world, but also because by pointing this out I seem to be yet again reifying the Hegelian narrative about the static and backward Mongols who remained outside the greater flow of humanity to the ultimate end game of Western modernity (Elverskog 2004, 137-139). Indeed, as noted above, I readily understand that much of the recent work on printing around the world is to show precisely that printing was not the exclusive domain of Europeans and thus to use the parlance, one can thereby "provincialize Europe," or else "destabilize" the narrative of modernity, or quite simply show - as Victor Lieberman has so eloquently done (2009) - that printing was one of the many world-wide elements that shaped the early modern world. And while in theory I support and agree with all of these scholarly endeavours, the case of the Mongols seems to point in a different direction.

In fact, when I first started thinking about this issue I was even tempted to make a grand case based on Heidegger's critique of technology that was picked up by the Frankfurt School in order to castigate precisely the horrors of western modernity (Adorno and Horkheimer 2002). Which, in short, can be summed up by arguing that if printing created modernity it therefore led not only to the discovery of the Higgs-Boson, but also to Zyklon-B and the death chambers at Auschwitz. Thus by avoiding the "enframing" - to use Heidegger's term - of technology as the be-and-end all of existence - as we have and continue to do in the West - it can potentially be argued that by not adopting printing and the salvific narrative of technology, the Mongols thereby avoided the horrors of modernity. And, of course, I can well imagine that some Mongol nationalists, or reactionary Mongolists, could take such an idea and run with it; ${ }^{6}$

6 Unfortunately, the rise of the far right in Mongolia has not received the scholarly attention it deserves; however, the lyrics of the song "Don't Overstep the Limit You Chinks" by the popular Mongolian rap band Dörwön Züg gives a sense of its sensibilities.

We are Chinese, you are paupers sitting on gold

We have the money to buy everything you've got

Your women, land, dignity, down to everything you own.

You just wait and see!

Crushing rice in their hand, they took hold of our state for themselves

If the state entrusted by us was entrusted to the Chinks

(We would) shoot and slaughter them all (until) none (is left)

Mongolian girls who become 5 penny whores below them 
however, I confess I'm wary of such grand speculations. Nevertheless, I do think it is valid to think about the epistemological and ontological implications of technology's impact on a society, such as was clearly the case with printing. Yet, I am not a philosopher, and thus the larger questions about the existential consequences for the Mongols of avoiding print culture I will leave aside for now.

Though in doing so it is no doubt relevant to note that the situation among the Mongols and Tibetans was quite different in this regard. Indeed, as evidenced in previous work (Schaeffer 2009) - as well as all the articles in this volume - it is clear that printing had a profound impact on Tibetan culture. And these transformations can both be traced out, and used to reveal new insights into Tibetan history. Yet, as I have been arguing, I do not think the same can be said in terms of Mongolian print culture, this disjuncture clearly needs to be explained. To do so, I would like to suggest some possible reasons for why this may have been the case.

Snub-nosed Mongolian stray dogs as their food menu

The poison goes straight down to our empty stomach

Right away, (they) suck out the Mongol blood

We will make trouble for you, we'll make you pay dear

You'll give up, saying "Come here, come here," you'll click the tongue ha ha

You Chink who stabs from behind you'll be dead by tomorrow

While we think it's easy to click click the word "Chinese," they really overstep the limits

On the land of our country Chinese slippers' prints do not lack, they are in excess

Us Mongols who became men following men's principles

Are we going to let ourselves be humiliated by these shitty Chinks?

Call the Chinese, call call call; and shoot them all all all

Call the Chinese, call call call; and shoot them all all all...

They rape young girls and abandon them, dirty shits

You weak candy wraps with your fetid breath and your small body

Time has come for you to go back bastards

Slide out and die motherfuckers

(http://www.gregorydelaplace.com/images/docs/zugdavaren.pdf). For more on this movement and its connection with Chinese mining companies, corruption, and a whole host of other factors see the following articles: http://www.time.com/time/magazine/ article/o,9171,1910893,oo.html; http://www.guardian.co.uk/world/2010/aug/o2/mongolia-farright; http://www.economist.com/node/21543113; http://www.theglobalmail.org/feature/ the-filthy-rich-and-the-racists-in-mongolias-mining-boom/16/. 
Some may want to argue that Mongol cultural resistance to print culture lies in the largely Qing imperial initiative behind most of the Mongolian printed corpus. Whereby the Mongol rejection of print culture was thereby somehow "anti-colonial." I would completely discount such a reading (Elverskog 2005), since to a large extent it is evident that the Mongols were loyal supporters of the Qing and would therefore presumably have engaged the expanding print culture that the Manchu court made available to the Mongols (Elverskog 2006a). The Mongols therefore not only had access to the ever-expanding corpus of Mongolian printed material, but also the even larger corpora of printed Chinese and Tibetan material. And as we know, the Mongols were avid consumers of both of these other print cultures. ${ }^{7}$ Thus the fact that the Mongols were "using" - buying, reading, gifting, worshipping - materials in both Chinese and Tibetan clearly impinged upon the use, circulation, and possible impact that Mongolian printed material may have had on Mongolian culture more broadly. Indeed, the prestige carried by both Tibetan and Chinese on account of the Dharma and literati culture clearly played a role in not only diminishing the power of Mongolian print culture, but also to a certain extent even hindered the very development of an autochthonous Mongolian literary culture. $^{8}$

The elevation of Tibetan as the liturgical lingua franca across Inner Asia thus profoundly impacted the development and growth of not only Mongolian literary culture, but also Mongolian Buddhism. So much so in fact that leading Mongol clerics such as Mergen Gegen (1717-1766) tried to address this problem by creating entirely new Buddhist liturgies in Mongolian (Humphreys and Ujeed 2013, 65-114); however, these efforts ultimately failed on account of the enormous prestige placed upon both Tibetan and Chinese. Thus in many ways it is no surprise that Mongolian printed material came to be eclipsed as Tibetan language sources came to dominate. Indeed, when thinking about the history of print culture among the Mongols, the absence of vernacularization and all the benefits that supposedly flowed out of it were therefore short-circuited. And this dynamic clearly played a role in diminishing the power, or lure, of the enormous amount of Mongolian works printed in Beijing, Doloon Nuur, and elsewhere. They simply could not compete with the prestige of Tibetan (and/ or Chinese). Moreover, and even more tragically, most of these works could

7 On the influence of Chinese print culture on Mongolian culture see, for example, Bawden (1979, 1983, 2002), Clunas (1980), and Nasanurtin (1999).

8 On the lingering consequences of this Qing-period dynamic see Elverskog 2006. 
not even be read; and thus, if anything, they simply signified what they were: vehicles of merit production and monuments of state power. As such, even if voluminous, the Mongolian printed material was simply not enough by itself to generate what one can call a print culture and its consequences as explored in the work of Benedict Anderson.

In short, Mongolian print culture never developed a life of its own. Squeezed between the omnipresent and prestige-filled corpora of Chinese and Tibetan material the corpus of Mongolian printed material never had a chance. Of course, as with any "smaller" language grappling with larger ones - such as with English and Putonghua 普通话 today (Crystal 1997; Tsu 2011) - there are invariably numerous issues of power and history at play, and the case of Mongolian print culture in the face of Chinese and Tibetan was no different. Indeed, while the prestige of these two languages on account of their link with Buddhism and literati culture clearly played a role, there were other factors involved that need to be explored in order to fully explain the failure of a Mongolian print culture to develop.

For example, in the case of Chinese print culture and its relationship to Mongolian culture and its valuation of knowledge, it is relevant to note that the Mongols were excluded from the imperial examination system. Which had huge consequences, since as Elman has noted, the educational function of the civil examination system was the "social, political, and cultural reproduction of the late imperial status system" (Elman 2000, xxviii). Thus being denied access to the standard means of producing status in late imperial China clearly had an impact on the Mongols and thus it is no surprise that in the nineteenth century Injannashi was to rail against this exclusionary policy (Elverskog 2008a, 98-100). However, before that time this situation did not apparently receive much attention, and as such, this lack of concern clearly needs to be explained. Not only in terms of how this influenced the Mongols' engagement with the Qing's various print cultures, but also in terms of how it shaped broader understandings of knowledge acquisition among the Mongols and its relation to book culture. In short, did Qing imperial policies - in tandem with Tibetanization - play a role in short-circuiting the common developmental arc of print culture among the Mongols? Perhaps, but the actual dynamics of this process are now unfortunately speculative.

Yet, what is not speculative is that Mongolian print culture never really took off beyond what may be termed the fetishized object of the Buddhist book cult. And while this fact can no doubt be partially explained by the realities of Tibetanization and Qing policies, there were no doubt other factors also at play. One of these was no doubt cost; namely, while one can look at Heissig's work on the printed Mongolian material produced in Beijing (1954), or look at 
all the printed material housed in Mongolian collections around the world, ${ }^{9}$ and thereby somehow be amazed, or struck, by the remarkable amount of woodblocks produced, one also does not get a sense of how much these things cost. Or how difficult they were to produce. For example, the colophon of the 1656 Suvarnaprabhäsa tells us that it took three months to carve the blocks for that one text (Kara 2000, 179). Of course, in the Manchu capital, where the initial expenditure for producing something as monumental as the Kanjur or Tanjur was initially borne by the court, we should rightly ask what happened afterwards? In other words, once they had the blocks carved and stored in Beijing, how much would it cost to get a full copy of the Kanjur in Mongolia? Based on a monastic inventory that I came across in Inner Mongolia it was 5000 liang of silver, which by any stretch of the imagination was a huge sum of money at the end of the eighteenth century; especially for something that was not going to be read. Thus the financial burden of not only producing printed works, but also the subsequent realities of a small market demand were clearly aspects that hindered the development of Mongolian print culture.

Yet, above and beyond the issue of cost and the deeper structural problems of Tibetanization and other Qing policies, there is also another factor that may have played a role in hindering the development of Mongolian print culture. And that is aesthetics; in particular, the unattractive nature of many Mongolian printed books. Thus, unlike Tibetan printed books, which can be beautiful and easy to read, Mongolian blockprints are very often neither. A fact that may be attributable to the difficulty of carving blocks with the vertical Sogdo-Uygur script within the narrow confines of the traditional Buddhist pustaka format. However, above and beyond such technical difficulties there is also the more intangible issue of beauty, and in this regard a valuable parallel can be drawn between the Mongols and the history of printing in the Islamic world, where printing was also famously not adopted even though they had the technology (Elverskog 2010). In trying to explain this Muslim rejection of print technology Blair has recently argued that aesthetics actually played a large role; namely, printed Arabic could never compete with the artistry of calligraphy (2006, 486-7). Which is an argument that no doubt also resonates in the Sinoscript

9 The major collections of Mongolian material include those in Berkeley (Bese 1977), Budapest (Kara 2000), Chicago (Krueger 1966), P.R.C. (Editorial Board of the Catalogue of Ancient Mongolian Books and Documents of China 2000), Copenhagen (Heissig 1971), Germany (Heissig 1961), Oslo (Heissig 1958), Paris (Ligeti 1930), Scheut (Heissig 1957/8), St. Petersburg (Uspensky 1999), Stockholm (Aalto 1953), Tokyo (Poppe et al. 1964), Ulan Ude (Tsyrempilov 2004), and Washington D.c. (Farquhar 1955). 
world; however, in the case of Arabic and Mongolian, both of which derive their scripts from Aramaic, the situation is particularly acute since blockprinted Arabic and Mongolian is very often nothing but a crude simulation of the calligraphic original. Thus in both cases it is very likely that this aesthetic concern - as well as the others articulated above - played a role in hindering the development of their own print cultures.

\section{4}

\section{Conclusion}

As the above has hopefully made clear there were no doubt many reasons for why a Mongolian print culture did not fully develop. But in addition to recognizing that such factors as language prestige, religious valuations, political policies, and aesthetics may have played a role in this phenomenon, it is also vital to recognize that the Mongols also quite simply never imagined printing as socially transformative. Thus the fact that they never actually developed a vernacular print culture and all the consequences that such a thing supposedly entails may have been a foregone conclusion. Or else it could quite simply have been the wrong question, and therein lies the Gutenberg fallacy.

\section{References}

Aalto, Pentii. 1953. A Catalogue of the Hedin Collection of Mongolian Literature. Stockholm: Statens etnografiska museet.

Adorno, T. W., with Max Horkheimer. 2002. Dialectic of Enlightenment, translated by Edmund Jephcott. Stanford: Stanford University Press.

Almogi, Orna. 2014. "Review of Edition, éditions: l'écrit au Tibet, evolution et devenir (eds. Anne Chayet et al. (Munich: Indus Verlag, 2010)." Journal of Asian Studies 72, 4: 992-993.

Amelung, Iwo. 2003. "Die 'Vier großen Erfindungen': Selbstzweifel und Selbstbestätigung in der chinesischen Wissenschafts-und Technikgeschichtsschreibung." In Selbstbehauptungsdiskurse in Asien: Japan-China-Korea, edited by Iwo Amelung et al., 243-272. München: Iudicium.

Bachner, Andrea. 2014. Beyond Sinology: Chinese Writing and the Scripts of Culture. New York: Columbia University Press.

Baron, Sabrina Alcorn, Eric N. Lindquist, and Eleanor F. Shevlin, eds. 2007. Agent of Change: Print Culture Studies after Elizabeth L. Eisenstein. Amherst and Boston: University of Massachusetts Press, in association with The Center for the Book, Library of Congress, Washington, DC. 
Barrett, T. H. 2008. The Woman Who Discovered Printing. New Haven: Yale University Press.

2014. From Religious Ideology to Political Expediency in Early Printing: An Aspect of Buddho-Daoist Rivalry. London: Minnow Press.

Bawden, Charles R. 1979. "Injanasi's novel Nigen dabqur asar." In Studia Sino-Mongolica: Festschrift für Herbert Franke, edited by K. Sagaster and M. Weiers. Wiesbaden: Steiner.

1983. "Injanasi's romantic novels as a literary tour-de-force." In Documenta Barbarorum: Festschrift für Walther Heissig zum 7o. Geburtstag, edited by K. Sagaster and M. Weiers. Wiesbaden: Harrassowitz.

2002. "A Chinese Source for an Episode in Injanasi's Novel Nigen Dabqur Asar."

In Tractata Tibetica et Mongolica, eds. K. Kollmar-Paulenz and C. Peter. Wiesbaden: Harrassowitz.

Bese, Lajos. 1977. The Mongolian Collection in Berkeley, California. Budapest: Akadémiai Kiadó.

Blair, Sheila S. 2006. Islamic Calligraphy. Edinburgh: Edinburgh University Press.

Chartier, Roger. 1994. The Order of Books: Readers, Authors, and Libraries on Europe between the Fourteenth and the Eighteenth Centuries. Stanford: Stanford University Press.

Cleaves, F. W. 1982. "The First Chapter of an Early Mongolian Version of the Hsiao Ching." Acta Orientalia Hungaricae 36: 69-88.

2001. An Early Version of the Hsiao Ching (The Book of Filial Piety). Chapters Seven, Eight and Nine...Chapters Ten Through Seventeen. Bloomington: The Mongolia Society.

Clunas, A. Craig. 1980. "The Prefaces to Nigen Dabqur Asar and their Chinese Antecedents." Zentralasiatische Studien 14, 1: 139-194.

Crystal, David. 1997. English as a Global Language. Cambridge: Cambridge University Press.

Dane, Joseph A. 2003. The Myth of Print Culture: Essays on Evidence, Textuality, and Bibliographical Method. Toronto: University of Toronto Press.

_ 2009. "Print Culture Mythology and Some Fifteenth-Century Printing Types." Unpublished paper presented at the Global History of Printing Symposium, UsC, April 24. Available at http://college.usc.edu/emsi/conferences/index.html

Editorial Board of the Catalogue of Ancient Mongolian Books and Documents of China. 2000. Dumdadu ulus-un erten-ü monggol nom bicig-ün yerüngkei garcag. Catalogue of Ancient Mongolian Books and Documents of China. Beijing: Beijing Tushuguan Chubanshe.

Elman, Benjamin A. 1984. From Philosophy to Philology: Intellectual and Social Aspects of Change in Late Imperial China. Cambridge (MA): Council on East Asian Studies, Harvard University. 
- 2000. A Cultural History of Civil Examinations in Late Imperial China. Berkeley: University of California Press.

Elverskog, Johan. 2004. "Things \& the Qing: Mongol Culture in the Visual Narrative." InnerAsia 6: 137-178.

2005. "Sagang Sechen on the Qing Conquest." In The Black Master: Essays on Central Eurasia in Honor of Professor György Kara on his 7oth Birthday, edited by Stéphane Grivelet, Ruth Meserve, Àgnes Birtalan, Giovanni Stary, 43-56. Wiesbaden: Harrassowitz.

2006. "Two Buddhisms in Contemporary Mongolia." Contemporary Buddhism 7, 1: 29-46.

2006a. Our Great Qing: The Mongols, Buddhism, and the State in Late Imperial China. Honolulu: University of Hawai'i Press. 2008. "The Mongolian Big Dipper Sutra." Journal of the International Association of Buddhist Studies 29, 1: 87-124.

_ 2008a "Injannashi, the anti-Cervantes" In Biographies of Eminent Mongol Buddhists, edited by Johan Elverskog, 81-104. Sankt Augustin: International Institute for Tibetan and Buddhist Studies. 2010. “A Buddhist Origin for Islamic Blockprinting?" The Muslim World 100, 2-3: 287-301.

Farquhar, David M. 1955. "A Description of the Mongolian Manuscripts and Xylographs in Washington, D.C." Central Asiatic Journal 1: 161-218.

Febvre, Lucien and Henri-Jean Martin. 1990. The Coming of the Book: The Impact of Printing, 1450-1800. London: Verso.

Franke, Herbert. 1962. Mittelmongolische Kalendarfragmente aus Turfan. München: Sitzungberichte der Bayrischen Akademie der Wissenschaften.

Furth, Charlotte. 2009. "Comments on the Origin of Printing." Unpublished paper presented at the Global History of Printing Symposium, USC, April 24. Available at http://college.usc.edu/emsi/conferences/index.html

Heissig, Walther. 1954. Die Pekinger lamaistischen Blockdrucke in mongolischer Sprache. Wiesbaden: Harrassowitz.

1957/8. "The Mongol Manuscripts and Xylographs of the Belgian ScheutMission." Central Asiatic Journal 3: 161-189.

1958. "A Description of the Mongolian Manuscripts in the University-Library Oslo." Acta Orientalia 23: 92-106.

1961. Mongolische Handschriften Blockdrucke Landkarten. Wiesbaden: Franz Steiner Verlag.

1961-1962. "Eine kleine mongolische Klosterbibliothek aus Tsakhar." Jahrbuch des Bernischen Historischen Musuems in Bern 1961-1962: 557-590.

1962. Beiträge zur Übersetzungsgeschichte des mongolischen buddhistischen Kanons. Göttingen: Vandenhoeck \& Ruprecht. 
1971. Catalogue of Mongol Books, Manuscripts and Xylographs. Copenhagen:

The Royal Library.

— 1976. Die mongolischen Handschriften-Reste aus Olon süme Innere Mongolei (16.-17.Jhdt.). Wiesbaden: Otto Harrassowitz.

Humphrey, Caroline, and Hürelbaatar Ujeed. 2013. A Monastery in Time: The Making of Mongolian Buddhism. Chicago: University of Chicago Press.

Johns, Adrian. 1998. The Nature of the Book: Print and Knowledge in the Making. Chicago: University of Chicago Press.

Kara, György. 1979. "Weitere mittelmongolische Bruchstücke aus der Berliner Turfansammlung." Altorientalische Forschung 6:187-203. 2000. The Mongol and Manchu Manuscripts and Blockprints in the Library of the Hungarian Academy of Sciences. Budapest: Akadémiai Kiadó.

2005. Books of the Mongolian Nomads: More than Eight Centuries of Writing Mongolian. Bloomington: Indiana University, Research Institute for Inner Asian Studies.

Kingwell, Mark. 2013. “Beyond the Book." Harper's Magazine, August. http://harpers.org/ archive/2013/o8/beyond-the-book/ Accessed October 5, 2013.

Kornicki, Peter. 2012. "The Hyakumantō Darani and the origins of printing in eighthcentury Japan.” International Journal of Asian Studies 9: 1-28.

Krueger, John R. 1966. "Catalogue of the Laufer Mongolian Collections in Chicago." Journal of the American Oriental Society, 86, 2: 156-183.

Lieberman, Victor. 2009. Strange Parallels: Southeast Asia in Global Context, c. 800-1830. Volume 2, Mainland Mirrors: Europe, Japan, China, South Asia, and the Islands. New York: Cambridge University Press.

Ligeti, Louis. 1930. "La collection mongole Schilling von Canstadt à la Bibliothèque de l'institut." T'oung pao 27, 119-178.

_ 1964. "Les fragments du Subhāsitaratnanidhi mongol en écriture 'phags-pa. Mongol pré-classique et moyen mongol." Acta Orientalia Hungaricae 17: 239-292.

McKitterick, David. 2003. Print, Manuscript, and the Search for Order, 1450-1830. Cambridge: Cambridge University Press.

Marks, Robert B. 2002. The Origins of the Modern World: A Global and Ecological Narrative. Lanham: Rowman \& Littlefield.

Morozov, Evgeny. 2013. To Save Everything, Click Here: The Folly of Technological Solutionism. New York: Public Affairs.

Nasanurtin Hasbatar. 1999. Mongolische "Heftgeschichten" und chinesisiche Ritterromane: Eine Untersuchung über die chinesichen Einflüsse auf die mongolische Literatur. Wiesbaden: Harrassowitz.

Poppe, Nicholas, Leon Hurwitz and Hidehiro Okada. 1964. Catalogue of the ManchuMongol Section of the Toyo Bunko. Tokyo: The Toyo Bunko. 
Schäfer, Dagmar. 2011. The Crafting of the 10,00o Things: Knowledge and Technology in Seventeenth-Century China. Chicago: The University of Chicago Press.

Schaeffer, Kurtis. 2009. The Culture of the Book in Tibet. New York: Columbia University Press.

Siebert, Martina. 2012. "Making Technology History." In Cultures of Knowledge: Technology in Chinese History, edited by Dagmar Schäfer, 253-28. Leiden: Brill.

Tsu, Jing. 2011. Sound and Script in Chinese Diaspora. Cambridge (MA): Harvard University Press.

Tsyrempilov, Nikolay. 2004. Annotated Catalogue of the Collection of Mongolian Manuscripts and Xylographs MI of the Institute of Mongolian, Tibetan, and Buddhist Studies of the Siberian Branch of the Russian Academy of Sciences. Miyagi: Center for Northeast Asian Studies, Tohoku University.

Uspensky, Vladimir L. 1999. Catalogue of the Mongolian Manuscripts and Xylographs in the St. Petersburg State University Library. Tokyo: Institute for the Study of Languages and Cultures of Asia and Africa.

Weiers, Michael. 1967. "Zum Textfragment тм 40 aus der Berliner Turfansammlung." Zeitschrift der Deutschen Morgenländischen Gesellschaft 117: 329-352. 